\title{
Benthic macroinvertebrate community in the Sinos river drainage basin, Rio Grande do Sul, Brazil
}

\author{
M. P. Barros ${ }^{a}$, L. M. Gayeski ${ }^{a}$ and J. G. Tundisi ${ }^{b}$ \\ a'Zoology Laboratory, School of Health Sciences, Universidade Feevale - Feevale, Campus II, \\ RS-239, 2755, CEP 93352-000, Novo Hamburgo, RS, Brazil \\ 'Instituto Internacional de Ecologia - IIE, Rua Bento Carlos, 750, CEP 13560-660, São Carlos, SP, Brazil \\ *e-mail: barrospm@cpovo.net
}

Received: March 3, 2015 - Accepted: April 16, 2015 - Distributed: August 31, 2016

(With 5 figures)

\begin{abstract}
Aquatic macroinvertebrate fauna is a relevant component of limnic continental aquatic ecosystems, playing an important role in several processes with relevant biocomplexity. The present study characterized the benthic macroinvertebrate fauna found in three hydric bodies in the Sinos river drainage basin regarding community structure. Sample was collected from January to December 2013 in three locations in the basin: the city of Caraá $\left(29^{\circ} 45^{\prime} 45.5^{\prime}{ }^{\prime} \mathrm{S} / 50^{\circ} 19^{\prime} 37.3^{\prime \prime} \mathrm{W}\right)$,

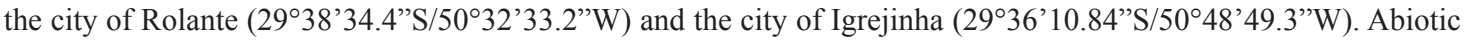
components ( $\mathrm{pH}$, dissolved oxygen and temperature) were registered and collected samples were identified up to family type. Average annual $\mathrm{pH}$, dissolved oxygen and temperature were similar in all locations. A total of 26,170 samples were collected. Class Insecta (Arthropods) represented $85.5 \%$ of total sample. Platyhelmintes, Mollusca and Annelida samples were also registered. A total of 57 families were identified for the drainage basin and estimators (Chao-1, Chao-2 and jackknife 2) estimated richness varying from 60 to 72 families.
\end{abstract}

Keywords: aquatic invertebrates, community structure, diversity indices.

\section{A comunidade de macroinvertebrados bentônicos da bacia hidrográfica do rio dos Sinos, Rio Grande do Sul, Brasil}

\begin{abstract}
Resumo
A fauna de macroinvertebrados aquáticos é um relevante componente dos ecossistemas aquáticos límnicos continentais, atuando em vários processos de importante biocomplexidade. O presente estudo caracterizou a fauna de macroinvertebrados bentônicos em três corpos hídricos da Bacia Hidrográfica do Rio dos Sinos, em relação a estrutura da comunidade. Amostragens foram realizadas de janeiro a dezembro de 2013 em três locais na bacia: Município de

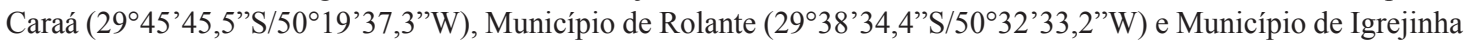
$\left(29^{\circ} 36^{\prime} 10,84^{\prime} \mathrm{S} / 50^{\circ} 48^{\prime} 49,3^{\prime}\right.$ 'W). Variáveis abióticas ( $\mathrm{pH}$, oxigênio dissolvido e temperatura) foram registradas e os exemplares coletados identificados até família. As médias anuais de $\mathrm{pH}$, oxigênio dissolvido e temperatura foram similares em todos os pontos. Um total de 26.170 exemplares foi amostrado. A Classe Insecta (Arthropoda) representou $85,5 \%$ do total. Platyhelmintes, Mollusca e Annelida também foram registrados. Foram determinadas 57 famílias para a bacia hidrográfica e os estimadores (Chao-1, Chao-2 e jackknife 2) projetaram uma riqueza variando de 60 a 72.
\end{abstract}

Palavras-chave: invertebrados aquáticos, estrutura da comunidade, índices de diversidade.

\section{Introduction}

Conservation of biodiversity in general and specifically aquatic biodiversity is fundamental to maintain biosphere processes and to keep the course of the evolution of natural systems, however, in many tropical regions, studies on biodiversity are still at an intermediate stage and not very advanced in knowledge, especially in regions with internal deltas of large rivers in South America, which are active centers of evolution due to their biodiversity and gene flow interaction (Tundisi and Matsumura-Tundisi, 2003).
Invertebrates are of major ecologic importance in freshwater environments; they play a decisive role in organic matter fragmentation and decomposition and are important elements in food chains and food webs. They are directly involved in energy flow and perform an effective role in biogeochemical cycles. Their abundance and diversity are associated to different factors, such as trophic level of aquatic systems, pollution and contamination levels, habitat availability and disturbance frequency (Ismael et al., 1999). 
According to Silveira and Queiroz (2006), benthic macroinvertebrates are a group of animals visible to the naked eye, made up mainly by mollusks, crustaceans and insects that inhabit the substrate at the bottom of rivers. They are important in limnic environments, serving as food for fish and taking part in the energy flow and nutrient cycling (Ayres-Peres et al., 2006). As they reflect changes in the environment, they are recommended as bioindicators of water quality (Bueno et al., 2003), representing an important tool to understand the functioning and structure of lotic ecosystems (Galdean et al., 2001).

According to Franz et al. (2010), the Sinos river basin is among the most populated in the state of Rio Grande do Sul and represent a history marked by European colonization which took place from the 19th century until the 1940's. Occupation of lowlands and hillsides caused changes in the characteristics of natural areas. Forests were replaced by rural areas, and later by urban intensification. The impact of human activity, mainly the pollution of water with domestic sewage without treatment, add up along the river, and high levels of fecal coliform reflect the great sanitation deficit in the drainage basin, especially along the middle and lower courses of the Sinos river (Blume et al., 2010).

There is few available data on the structure of the benthic macroinvertebrate community along the drainage basins in the state of Rio Grande do Sul, highlight is given to studies by Bueno et al. (2003), Stenert et al. (2004), Volkmer-Ribeiro et al., (2004), Ayres-Peres et al. (2006), Piedras et al. (2006), Buckup et al. (2007), Milesi et al. (2009) and Biasi et al. (2010). The following studies are highlighted for the drainage basin of the Sinos river: Mansur and Pereira (2006), Strieder et al. (2006), Bieger et al. (2010) and Maltchik et al. (2010). The objective of the present study is to characterize the benthic macroinvertebrate fauna found in three water bodies located in the Sinos river drainage basin regarding community structure.

\section{Material and Methods}

\subsection{Study area}

The Sinos river drainage basin is located in the northeastern region of the state of Rio Grande do Sul, Brazil $\left(29^{\circ} 20^{\prime}-30^{\circ} 10^{\prime} \mathrm{S} / 50^{\circ} 15^{\prime}-51^{\circ} 20^{\prime} \mathrm{W}\right)$, and covers two geomorphic provinces: the Southern Plateau and the Central Depression. It is part of the Guaíba drainage basin and presents an area of approximately $800 \mathrm{~km}^{2}$, including 32 cities (FEPAM, 2014). The Sinos river drainage basin provides water to about 1.3 million people, with a population density of approximately 300 people per square kilometer, some urban areas and densely populated and area located along the lower course of the river. The region presents diversified industrial production: footwear and leather, mechanics and metallurgy, tourism and hospitality, where the lower portions of the drainage basin are under strong anthropic pressure due to the growth of the largest industrial park in the state (Blume et al., 2010).

\subsection{Sampling sites}

In order to determine physical and chemical characteristics, benthic macroinvertebrate and water samples were collected in three different sites along the drainage basin (Figure 1), in the major water bodies: upper Sinos river, Rolante river and Paranhana river, always in superficial waters of the water body itself.

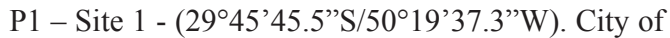
Caraá. Established in Lageadinho, this sampling site is located in the beginning of the formation of the Sinos river, although it is not characterized as the source of the river, as it already presents the influence of some small contributors. At this location, there are strong currents and whenever compared to the other two sites the bottom is made up of a rocky substrate, pebbles with various sizes intermingled with little decomposing organic matter. The city presents an area of 29538 hectares of which $23 \%$ are still originally covered by the Atlantic forest (Fundação SOS Mata Atlântica, 2014), and a estimated population of 7742 inhabitants (IBGE, 2010). Sampling point does not suffer the impact of great urban conglomerates located on upstream, thus the anthropic impact is considered low.

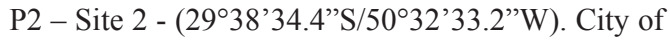
Rolante. Established in a location best known as "Reichert", sampling point is located in the Rolante River, five kilometers upstream of city center (urban density) and receives contributions from rivers Riozinho and Mascarada, the river drains an area of $500 \mathrm{~km}^{2}$. Sampling point is located $22 \mathrm{~km}$ from the mouth of the Sinos river, which is located in the rural area of the city of Taquara. The river currents are strong at sampling site and the bottom is made up of a sandy and rocky (pebbles) substrate, with various sizes intermingled with decomposing organic matter made up mainly of tree leaves from riparian vegetation located upstream. A greater environmental heterogeneity is found at this point with the decomposition of the sandy substrate. The city presents an area of 29675 hectares of which 17\% are still originally covered by the Atlantic forest (Fundação SOS Mata Atlântica, 2014), and a estimated population of 20479 inhabitants in 2013 (IBGE, 2010). Sampling point is under the impact of large urban conglomerates located upstream, such as the cities of Riozinho and São Francisco de Paula.

P3 - Site 3 - (29³6' $\left.10.84^{\prime \prime} \mathrm{S} / 50^{\circ} 48^{\prime} 49.3^{\prime \prime} \mathrm{W}\right)$. City of Igrejinha. Established in the "Casa da Pedra" district, sampling site is located in the Paranhana river, five kilometers downstream of city center (urban density) and 15 kilometers from the mouth of the Sinos river, which is located in the rural area of the city of Taquara, the river drains an area of $580 \mathrm{~km}^{2}$. The river currents are strong at sampling site and the bottom is made up of a sandy and rocky (pebbles) substrate, with various sizes intermingled with decomposing organic matter made up mainly of tree leaves from riparian vegetation located upstream. A greater environmental heterogeneity is found at this point with the decomposition of the sandy substrate. The city presents an area of 13557 hectares of which $22 \%$ are still originally covered by the Atlantic forest (Fundação SOS 


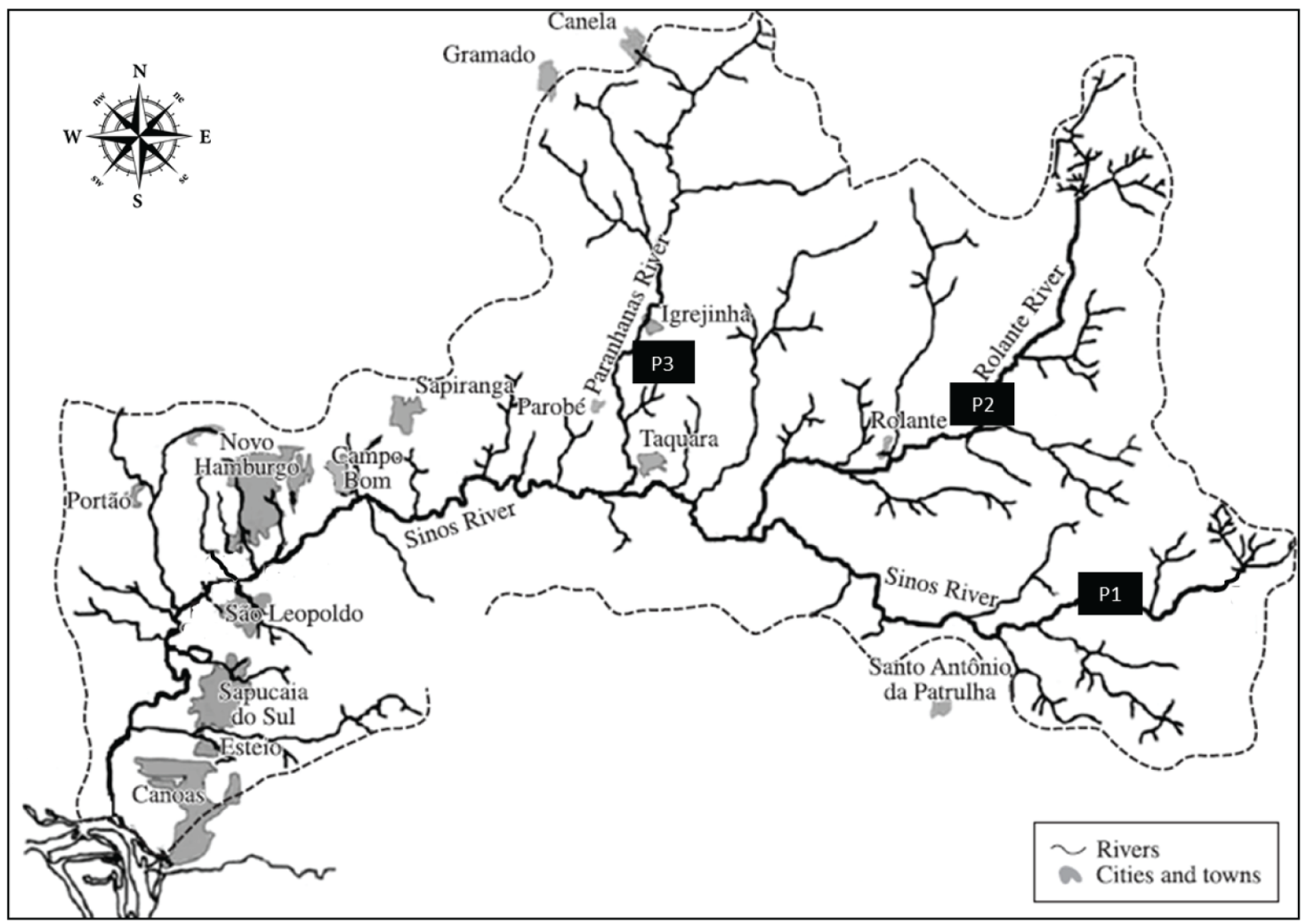

Figure 1. Location of the sampling sites (P1, P2 and P3), in the study area of the Sinos River basin, Southern Brazil, Rio Grande do Sul.

Mata Atlântica, 2014), and an estimated population of 33711 inhabitants in 2013 (IBGE, 2010). At this point, the Salto Dam System is important for the water dynamics of the river, since the dam system enables the regularization and transposition of water from the Caí river basin to the Sinos river basin for the production of electricity since 1956 through the Paranhana river (Macedo, 2010), thus, the water from the Caí river flows through this site in an inconstant and variable manner with maximum water flow of up to $11.6 \mathrm{~m}^{3} / \mathrm{s}$ for this transposition. Sampling point is partially under the impact of large urban conglomerates located upstream, such as the cities of Três Coroas, Gramado, Canela and São Francisco de Paula.

Measurement of dissolved oxygen was conducted by the Analytic Department at FEEVALE University, a FEPAM-RS certified laboratory. Sample collection, as well as all measurements, was carried out according to the Standard Methods for Examination of Water and Wastewater, 22nd Ed (Rice et al., 2012). Water temperature and $\mathrm{pH}$ were recorded in the field by using $\mathrm{pHmetro}$ Hanna Instruments (HI 98128).

BIOESTAT 5.0 (Ayres et al., 2007) and PAST (Hammer et al., 2001) were used for statistical analysis and biotic index calculations. Student's t-test was used to compare H value (Shannon Diversity Index) between the points. Group method was considered to calculate Morisita
Similarity Index $\left(\mathrm{S}_{\mathrm{M}}\right)$. Unweighted Pair Group Method with Arithmetic Mean (UPGMA) was used, the result is represented by a dendrogram. This analysis was carried out by software PAST - Version 2.16. (Hammer et al., 2001). Non-parametric richness estimators: Chao-1, Chao-2 and second order jackknife, Colwell and Coddington (1994) revised these estimator and concluded that Chao-2 and second order jackknife present better performance.

\subsection{Macroinvertebrate sampling}

Macroinvertebrate and water sampling to determine physical and chemical characteristics took place from January to December 2013 . A $60 \mathrm{~cm} \times 40 \mathrm{~cm}\left(2400 \mathrm{~cm}^{2}\right)$ small fishing net with a $2 \mathrm{~mm}$ mesh size. Stream sampling method (kick-sampling) was used, which is a method that consists in moving pebbles at the bottom of the river with the objective of carrying dislocated animals into the net. All collected organisms were fixed on site using 70\% ethanol and were stored in plastic buckets. Once in the laboratory, the material was screened and the samples were indentified up to family type by using bibliography according to each taxonomic group (Lopretto and Tell, 1995; Merrit and Cummins, 1996; Moretti, 2004; Salles et al., 2004; Benetti et al., 2006; Mansur and Pereira, 2006; Costa et al., 2006; Froehlich, 2007; Mugnai et al., 2010; Carter et al., 2011). 


\section{Results and Discussion}

\subsection{Physical and chemical characteristics}

The three sampling sites are similar regarding limnologic characteristics of zonation, such as high current speed and substrate made up of fixed rocks, stones, gravel and thin sand, with deposition of mud and allochtonous leaves in small puddles or protected areas. Sampling sites can be traditionally classified as rhithron, although they do not present great slopes. Another important characteristic of the sampling points is the transparency of the water, with little suspended material that could be visually identified during sampling. Sites are located in erosion areas, which is caused by the pluviometric regime and not by sediment deposition.

In regards to temperature variation, Hawkes (1975) characterizes a ritral zone with an annual temperature variation that does not go over $20^{\circ} \mathrm{C}$, temperature varied less in the three sampling sites: Site 1 ( 8.1 up to $22.7^{\circ} \mathrm{C}$; $\mu=17.7{ }^{\circ} \mathrm{C}$ ), Ponto $2\left(9.0\right.$ up to $\left.24.6{ }^{\circ} \mathrm{C} ; \mu=19.0{ }^{\circ} \mathrm{C}\right) \mathrm{e}$ Ponto $3\left(9.0\right.$ up to $25.6^{\circ} \mathrm{C} ; \mu=21.2^{\circ} \mathrm{C}$ ). Site 1 presents the smallest observed amplitude, followed by Sites 2 and 3 (Figure 2), in regards to average annual temperature the same behavior occurred, with the average increasing towards the mouth of the basin. This classification based in thermal balance could cover stretches such as mountain rivers, but the sites are already located in areas that present a decrease in laminar flow.

Regarding $\mathrm{pH}$, annual average, calculated over 12 months, presented neutral values (Site $1-7.04$, Site $2-7.08$ and Site $3-6.85)$. These values are expected in continental natural waters and are among the variation predicted by CONAMA resolution No. 357/205 (Brasil, 2005) for class 1 waters. Extreme recorded $\mathrm{pH}$ values were 6.17 at Site 3 (the lowest) and 7.69 (the highest) at Site 1 (Figure 3). Most species of aquatic organisms are very sensitive to $\mathrm{pH}$ variations and very acidic or alkaline waters may be harmful to aquatic communities, therefore, the recorded $\mathrm{pH}$ variation is not a compromising factor for the maintenance of aquatic life in the sites that were studied. According to Esteves (1998), most continental water bodies have a $\mathrm{pH}$ that varies between 6 and 8 .

In regards to dissolved oxygen (DO), the annual average presented high values in all of the monitored sites: Site $1-8.71 \mathrm{mgO}^{2} \mathrm{~L}^{-1}$, Site $2-8.94 \mathrm{mgO} 2 \mathrm{~L}^{-1}$ and Site $3-8.42 \mathrm{mgO}_{2} \mathrm{~L}^{-1}$. The smalled recorded value was $7.3 \mathrm{mgO}_{2} \mathrm{~L}^{-1}$, in the month of December at Site 3, and the highest was $10,85 \mathrm{mgO}_{2} \mathrm{~L}^{-1}$, in the month of July at Site 2 . These are expected values for natural waters, being above values predicted by CONAMA resolution No. 357/205 (Brasil, 2005) for class 1 waters, not constituting a compromising factor for the maintenance of aquatic biota at the studied sites. It is important to observe the inverse relationship between high values of dissolved oxygen at all three sites (Figure 4) in the month of July 2013, with the lower temperatures (Figure 2) recorded during the same month. Schäfer (1985) notes that oxygen balance must be understood as the most important factor in assessing an aquatic ecosystem, still, he considers the phenomena that with temperature rise there is a decrease in solubility of the oxygen found in the water and an increase of intensity for most biological processes, which means a higher consumption of oxygen.

Statistically significant differences were not found among the annual averages for all three sites in regards to the following characteristics: temperature (ANOVA: $\mathrm{F}_{\text {calc }}: 1.28 \leq \mathrm{F}_{\text {crit }} 3.44$ );

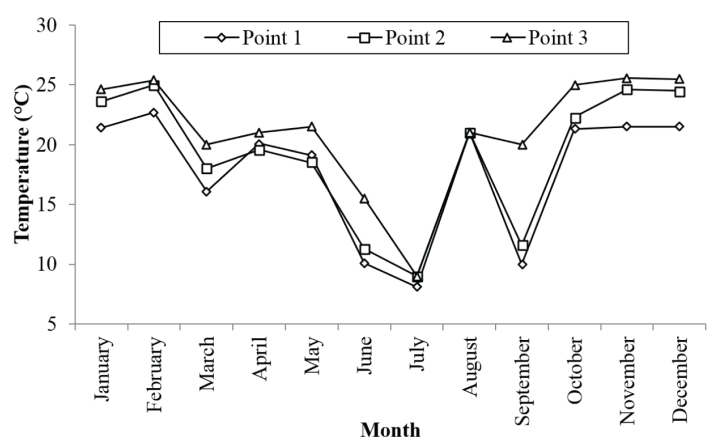

Figure 2. Variation in temperature of water the Sinos River - RS. Southern Brazil, Rio Grande do Sul. (January-December 2013).

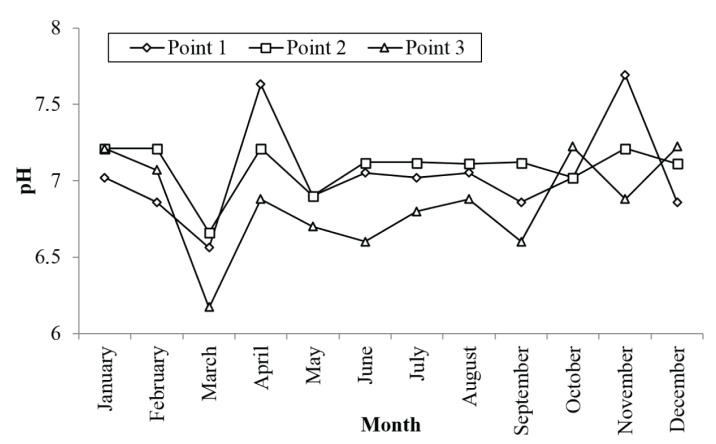

Figure 3. Variation in $\mathrm{pH}$ of water the Sinos River - RS. Southern Brazil, Rio Grande do Sul. (January-December 2013).

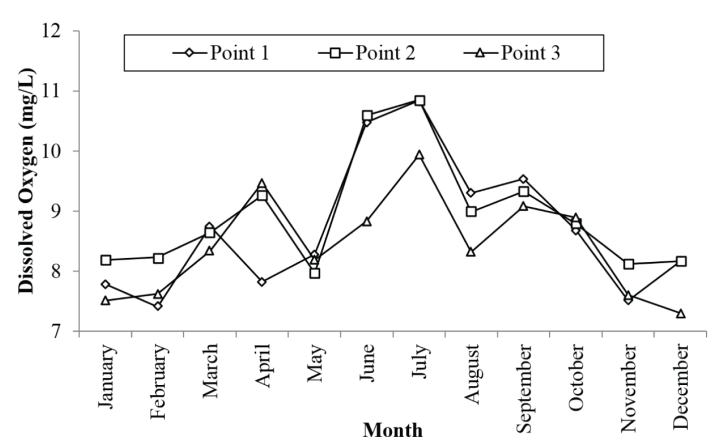

Figure 4. Variation in Dissolved Oxygen $(\mathrm{mg} / \mathrm{L})$ of water the Sinos River - RS. Southern Brazil, Rio Grande do Sul. (January-December 2013). 
$\mathrm{Ph}\left(\mathrm{ANOVAF}_{\text {calc }}: 2,437 \leq \mathrm{F}_{\text {crit }} 3.44\right)$ and dissolved oxygen (ANOVA: $\mathrm{F}_{\text {calc }}: 0.7958 \leq \mathrm{F}_{\text {crit }} 3.44 ; \alpha: 0.05$ ).

\subsection{Biodiversity, community structure and composition}

A total of 26,170 samples, including immature individuals, were collected during sampling period. From the total, 5647 specimens were sampled at Site 1 (Lageadinho,Caraá), 10444 were sampled at Site 2 (Reichert, Rolante) and 10079 were sampled at Site 3 (Casa de Pedra, Igrejinha). This number is closed to the value found by Buckup et al. (2007), who collected 28694 specimens during samplings in three rivers from the Pelotas river basin, state of Rio Grande do Sul, which can be characterized as Southern Brazilian mountain rivers.
High abundance of specimens at Sites 2 and 3 may be explained by the great quantity of allochthonus leaf material deposited among the pebbles in the river bottom, from the riparian vegetation located upstream. According to Bueno at al. (2003) the leaf material serves as food and shelter for maggots of many types of insects, as well as support for adult individuals during periods of drought. Greater substrate heterogeneity with the occurance of sand deposits in both sites may also be positively influencing the abundance of benthic macroinvertebrate species.

A total of 57 benthic macroinvertebrate families were recorded for this water basin, 51 families for Site 1, 42 for Site 2 and 35 families for Site 3 (Table 1). Classic diversity indices (Table 2) were established for all three sites, with the Shannon diversity index $(\mathrm{H})$ being the highest $(2,494)$

Table 1. Taxonomic groups and absolute frequencies of benthic invertebrates by families found in each sampling site in the Sinos River basin between January and December 2013. P1 - (2945'45.5"S/50¹9'37.3"W) City of Caraá, P2 - (29॰38’34.4”S/ 50॰32’33.2”W) City of Rolante, P3 - (29³6’10.84”S/5048’49.3”W) City of Igrejinha.

\begin{tabular}{|c|c|c|c|c|c|}
\hline Filo/Class & Order & Family & P1 & $\mathbf{P 2}$ & P3 \\
\hline Platyhelmintes & Tricladida & Dugesiidae & 8 & 0 & 277 \\
\hline Mollusca/ Gastropoda & & Cochliopidae & 58 & 9 & 3 \\
\hline Mollusca/ Gastropoda & & Ampullaridae & 10 & 21 & 0 \\
\hline Mollusca/ Gastropoda & & Planorbiidae & 1 & 0 & 0 \\
\hline Mollusca/ Gastropoda & & Lithogliphidae & 0 & 2,965 & 37 \\
\hline Mollusca/Bivalvia & & Cyrenidae & 3 & 105 & 199 \\
\hline Mollusca/Bivalvia & & Hyriidae & 0 & 0 & 1 \\
\hline Annellida/Oligochaeta & & Tubificidae & 19 & 10 & 13 \\
\hline Annelida/Hirudinea & & Glossiphonidae & 2 & 0 & 0 \\
\hline Arthropoda/Chelicerata & Acarina & "Hydracarina" & 12 & 1 & 0 \\
\hline Arthropoda/Crustacea & Isopoda & Cymothoidae & 6 & 0 & 0 \\
\hline Arthropoda/Crustacea & Decapoda & Palaemonidae & 8 & 0 & 0 \\
\hline Arthropoda/Crustacea & Decapoda & Trichodatylidae & 20 & 0 & 0 \\
\hline Arthropoda/Insecta & Hemiptera & Naucoridae & 104 & 216 & 158 \\
\hline Arthropoda/Insecta & Hemiptera & Veliidae & 82 & 37 & 2 \\
\hline Arthropoda/Insecta & Hemiptera & Gerridae & 1 & 0 & 0 \\
\hline Arthropoda/Insecta & Hemiptera & Pleidae & 1 & 0 & 0 \\
\hline Arthropoda/Insecta & Hemiptera & Mesoveliidae & 0 & 1 & 0 \\
\hline Arthropoda/Insecta & Hemiptera & Belostomatidae & 1 & 0 & 0 \\
\hline Arthropoda/Insecta & Coleoptera & Elmidae & 337 & 637 & 150 \\
\hline Arthropoda/Insecta & Coleoptera & Psephenidae & 69 & 752 & 6 \\
\hline Arthropoda/Insecta & Coleoptera & Gyrinidae & 25 & 4 & 0 \\
\hline Arthropoda/Insecta & Coleoptera & Staphilinidae & 7 & 30 & 5 \\
\hline Arthropoda/Insecta & Coleoptera & Dytiscidae & 3 & 0 & 0 \\
\hline Arthropoda/Insecta & Coleoptera & Curculionidae & 1 & 1 & 0 \\
\hline Arthropoda/Insecta & Coleoptera & Hydrophilidae & 0 & 17 & 2 \\
\hline Arthropoda/Insecta & Coleoptera & Dryopidae & 0 & 4 & 0 \\
\hline Arthropoda/Insecta & Coleoptera & Lutrochidae & 0 & 40 & 52 \\
\hline Arthropoda/Insecta & Diptera & Chironomidae & 1,239 & 1,967 & 497 \\
\hline Arthropoda/Insecta & Diptera & Tipulidae & 9 & 29 & 69 \\
\hline Arthropoda/Insecta & Diptera & Simulidae & 241 & 293 & 71 \\
\hline Arthropoda/Insecta & Diptera & Empididae & 2 & 2 & 0 \\
\hline Arthropoda/Insecta & Plecoptera & Perlidae & 67 & 167 & 3 \\
\hline
\end{tabular}


Table 1. Continued...

\begin{tabular}{|c|c|c|c|c|c|}
\hline Filo/Class & Order & Family & P1 & $\mathbf{P 2}$ & P3 \\
\hline Arthropoda/Insecta & Plecoptera & Gripopterygidae & 16 & 9 & 0 \\
\hline Arthropoda/Insecta & Megaloptera & Corydalidae & 34 & 47 & 113 \\
\hline Arthropoda/Insecta & Trichoptera & Philopotamidae & 65 & 115 & 22 \\
\hline Arthropoda/Insecta & Trichoptera & Hydropsychidae & 826 & 994 & 3,751 \\
\hline Arthropoda/Insecta & Trichoptera & Hydroptilidae & 12 & 1 & 1 \\
\hline Arthropoda/Insecta & Trichoptera & Leptoceridae & 49 & 152 & 32 \\
\hline Arthropoda/Insecta & Trichoptera & Glossosomatidae & 14 & 293 & 398 \\
\hline Arthropoda/Insecta & Trichoptera & Polycentropodidae & 6 & 13 & 1 \\
\hline Arthropoda/Insecta & Trichoptera & Calamoceratidae & 21 & 0 & 0 \\
\hline Arthropoda/Insecta & Trichoptera & Odontoceridae & 6 & 21 & 30 \\
\hline Arthropoda/Insecta & Trichoptera & Hydrobiosidae & 13 & 3 & 0 \\
\hline Arthropoda/Insecta & Trichoptera & Helichopsichidae & 3 & 13 & 1 \\
\hline Arthropoda/Insecta & Trichoptera & Sericostomatidae & 2 & 0 & 0 \\
\hline Arthropoda/Insecta & Odonata & Gomphidae & 13 & 143 & 24 \\
\hline Arthropoda/Insecta & Odonata & Corduliidae & 2 & 8 & 4 \\
\hline Arthropoda/Insecta & Odonata & Coenagrionidae & 128 & 40 & 2 \\
\hline Arthropoda/Insecta & Odonata & Megapodagrionidae & 4 & 0 & 0 \\
\hline Arthropoda/Insecta & Odonata & Calopterygidae & 18 & 1 & 1 \\
\hline Arthropoda/Insecta & Odonata & Libellulidae & 1 & 2 & 14 \\
\hline Arthropoda/Insecta & Ephemeroptera & Leptohyphidae & 967 & 291 & 629 \\
\hline Arthropoda/Insecta & Ephemeroptera & Baetidae & 452 & 290 & 340 \\
\hline Arthropoda/Insecta & Ephemeroptera & Leptophlebiidae & 618 & 691 & 3.000 \\
\hline Arthropoda/Insecta & Ephemeroptera & Caenidae & 3 & 0 & 0 \\
\hline Arthropoda/Insecta & Lepidoptera & Pyralidae & 38 & 9 & 171 \\
\hline TOTAL/individuals/site & & & 5,647 & 10,444 & 10,079 \\
\hline TOTAL/individuals & & & & 26,170 & \\
\hline TOTAL/family & & 57 families & 51 & 42 & 35 \\
\hline
\end{tabular}

Table 2. Diversity index of benthic invertebrate communities, calculated over samples collected in 2013. For all three sites, $\mathbf{N}$ : represents the total number and sampled specimens; S: represents the richness of the families; H': represents Shannon Index; $\mathbf{D}_{\mathrm{Mg}}$ : represents Margalef Index; Chao-1: represents a richness predictor and $\mathbf{E}$ ': represents an evenness index.

\begin{tabular}{ccccccc}
\hline Locais & $\mathbf{N}$ & $\mathbf{S}$ & $\mathbf{H}^{\prime}$ & $\mathbf{D}_{\mathbf{M g}}$ & $\mathbf{C h a o}_{\mathbf{1}}$ & $(\mathbf{E})$ \\
\hline Site 1 & 5,647 & 51 & 2,494 & 5,788 & 54 & 0,6344 \\
Site 2 & 10,444 & 42 & 2,416 & 4,431 & 45 & 0,6465 \\
Site 3 & 10,079 & 35 & 1,939 & 3,688 & 37 & 0,5454 \\
\hline
\end{tabular}

and Margalef Index also for Site $1(5,7880)$. The index difference found may be explained by the conditions of their calculations, as Shannon places value on species proportional abundance placing emphasis on richness and homogeneity, besides rare species, and the Margalef Index expresses richness weighed by sample size; however, both indices indicate Site 1 as the site with the greatest diversity. Although this site also presented less abundance in specimens (5647), the highest family absolute richness (51) was found here. The values may indicate an increase in degradation of the environmental quality of the basin from upstream to downstream sites, where there is a synergic effect from the increase of anthropic impact on the waters of the ecosystem. Student's t test revealed that there was no significant different between sampling sites when compairing H' between Sites 1 and 2; 1 and 3; and 2 and 3 (tcalc: 3.86 ; gl: 11,400; tcalc: 26.39; gl: 12,515; tcalc: 26.89; gl: 20,154; $\alpha$ : 0.05).

Shannon Diversity Index (H') varied from 1,939 (Site 3 ) to 2,494 (Site 1), which are values close to the ones found by Bueno et al. (2003) in small streams in the cities of Taquara and São Francisco de Paula, where H' varied from 1,000 to 3,580 .

Richness estimator Chao-1 calculated the possible number of families for each site (Site 1-54, Site 2-45 and Site 3 -37), where estimated basin value was 60 families, close to the 57 families recorded by this study. Stenert et al,m (2004) recorded 84 macroinvertebrate families in an extensive study conducted in 146 humid areas distributed along the state, therefore, so far, families found at the Sinos 
River basin represent $68 \%$ of the total amount registered for the state of Rio Grande do Sul.

Bieger et al. (2010), registered 54 macroinvertebrate families in small streams in the Sinos River basin. For these 54 families, the following were not registered in this study: Mycetopodidae and Sphaeridae (Bivalvia/Mollusca) and Lymnaeidae and Physidae (Gastropoda/Mollusca); Dogielinotidae (Arthropoda/Crustacea/Amphipoda) and Aeglidae (Arthropoda/Crustacea/Decapoda); Aeshnidae (Arthropoda/Insecta/Odonata); Noteridae (Arthropoda/ Insecta/Coleoptera); Euthyplocidae (Arthropoda/Insecta/ Ephemeroptera); Nepidae, Hydrometridae, Gelastocoridae and Corixidae (Arthropoda/Insecta/Hemiptera); Dixidae, Ceratopogonidae and Blephaceridae (Arthropoda/Insecta/ Diptera).

Most registered families $(n=30)$ were found at all three sampling sites along the Sinos River basin, with some singularities: Planorbiidae and Hyriidae (Mollusca) and Gerridae, Pleidae, Mesoveliidae and Belostomatidae (Arthropoda/Insecta) were found with only one specimen each, thus being considered rare in the samples collected. Sample collection method was probably not efficient for species of these families, as they are commonly found in continental freshwaters. The similarity dendrogram (Figure 5), found according to the Morisita Similatiry Index $\left(\mathrm{S}_{\mathrm{M}}\right)$, separated sites in two distinctive groups, revealing greater similarity between Sites 1 and 2 .

Equability (E'), also known as Pielou Evenness Index $(\mathrm{J})$, was calculated for all three sites (Table 2), with maximum value found at Site $2(0,06465)$ in an interval from $0>E \geq 1$; for this index, values close to one (1) show little

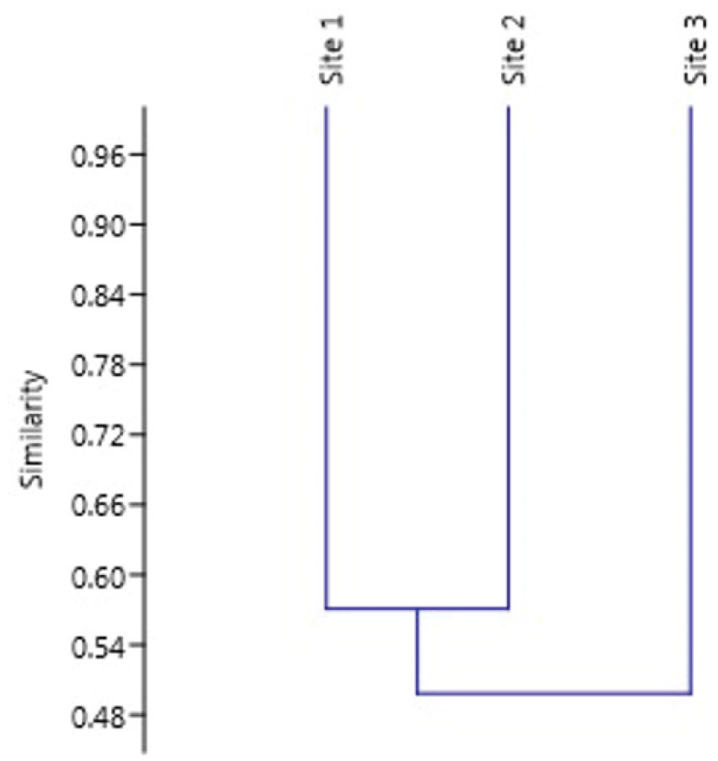

Figure 5. Dendrogram obtained by Morisita Index (UPGMA) representing the family similarity among sampling sites. Sinos River - RS. Southern Brazil, Rio Grande do Sul. (January-December 2013). Correlation Coefficient: $\mathrm{rc}=0.3117$. monospecific dominance, which means that theoretically this environment is more diverse.

Some families were abundant in the samples, such as Hydropsychidae $(n=5,571)$, Leptophlebiidae $(n=4,309)$, Chironomidae $(n=3,703)$ and Lithogliphidae $(n=3,002)$. When added, these four families $(n=16,585)$ represent $63.4 \%$ of total sample size, with Arthropoda/Insecta at the top 3. Arthropodes totaled 22,429 specimens (85.7\%) among the four phylum registered in the samples (Platyhelmintes, Mollusca, Annelida and Arthropoda) constituting the dominant macroinvertebrates in the basin.

From the total collected specimens, the Insecta Class represents $85.5 \%$ of the total amount. According to Rosenberg and Resh (1993), insects are dominant in continental water communities, being their great capacity of inhabiting and keeping high diversity in most water ecosystems one of the most surprising aspects of their biology. Among their abilities, special mention is made to their capacity to burry themselves in the substrate (sand, pebbles and leaves deposited at the bottom of the river) or to crawl in interstitial spaces, besides their respiratory adaptations which facilitate recolonization of different micro-habitats after catastrophic events such as floods (Kikuchi and Uieda, 1998; Buss et al., 2002).

According to Spilki and Tundisi (2010), the Sinos River basin is frequently reffered to as largely degraded; a series of impacts on the quality of the water, soil and air have been reported for this area over the last years. In the present study, this community was characterized by monitoring water macroinvertebrates, and it theoretically reflects the environmental conditions. For the basin, 57 families were found and predictor Chao-1 estimated 60 as an expected amount, Chao- 2 estimated 64 families and jackknife 2 predicted 72 families, however, when adding the families found by Bieger at al. (2010) which were not found in this study (16), we come to a total of 73 taxa $(57+16)$. This value can be considered high for the area, considering sampling sites are quite distinct from one another. In this context, it is possible to predict that the richness of invertebrate families found in the Sinos River basin can be elevated by using different sampling methods in areas which have yet to be explored.

\section{Conclusion}

Benthic macroinvertebrate species are differentially sensitive to many biotic and abiotic factors in their environment. Consequently, macroinvertebrate community structure has commonly been used as an indicator of the condition of an aquatic system. A total of 26,170 specimens were collected. A total of 57 families were identified for the drainage basin and estimators (Chao-1, Chao-2 and jackknife 2) estimated richness varying from 60 to 72 families. In the sampling sites, the community structure is typical of temperate rivers, despite having serious environmental impacts, the Basin of the Sinos River still has a high biodiversity and abundance of individuals. 


\section{References}

AYRES, M., AYRES JÚNIOR, M., AYRES, D.L. and SANTOS, A.A., 2007. BIOESTAT: aplicações estatísticas nas áreas das ciências biomédicas. Belém: Ong. Mamiraua.

AYRES-PERES, L., SOKOLOWICZ, C.C. and SANTOS, S., 2006. Diversity and abundance of the benthic macrofauna in lotic environments from the central region of Rio Grande do Sul state, Brazil. Biota Neotropica, vol. 6, no. 3, pp. 1-11. http:// dx.doi.org/10.1590/S1676-06032006000300006.

BENETTI, C.J., FIORENTIN, G.L., CUETO, J.A.R. and NEISS, U.G., 2006. Chaves de identificação para famílias de coleópteros aquáticos ocorrentes no Rio Grande do Sul, Brasil. Neotropical Biology and Conservation, vol. 1, no. 1, pp. 24-28.

BIASI, C., KÖNIG, R., MENDES, V., TONIN, A.M.; SENSOLO, D., SOBCZAK, J.R.S., CARDOSO, R., MILESI, S.V., RESTELLO, R.M. and HEPP, L.U., 2010. Waters biomonitoring using Benthic Macroinvertebrates: eight years of studies in streams of the Alto Uruguai Region (RS). Perspectiva, vol. 34, no. 125, pp. 66-77.

BIEGER, L., CARVALHO, A.B.P., STRIEDER, M.N., MALTCHIK, L. and STENERT, C., 2010. Are the streams of the Sinos River basin of good water quality? Aquatic macroinvertebrates may answer the question. Brazilian Journal of Biology = Revista Brasleira de Biologia, vol. 70, no. 4, suppl., pp. 1207-1215.

BLUME, K.K., MACEDO, J.C., MENEGUZZI, A., SILVA, L.B., QUEVEDO, D.M., and RODRIGUES, M.A.S., 2010. Water quality assessment of the Sinos River, Southern Brazil. Brazilian Journal of Biology = Revista Brasleira de Biologia, vol. 70, no. 4, suppl., pp. 1185-1193.

BRASIL. Ministério do Meio Ambiente. Conselho Nacional de Meio Ambiente, 2005 [viewed 17 March 2014]. Resolução $n^{\circ} 357$, 17 de março de 2005. Diário Oficial da República Federativa do Brasil, Brasília, 18 mar., pp. 58-63. Available from: http: \\www. mma.gov.br/port/conama/res/res05/res35705.pdf

BUCKUP, L., BUENO, A.A.P., BOND-BUCKUP, G., CASAGRANDE, M. and MAJOLO, F., 2007. The benthic macroinvertebrate fauna of highland streams in southern Brazil: composition, diversity and structure. Revista Brasileira de Zoologia, vol. 24, no. 2, pp. 294-301. http://dx.doi.org/10.1590/S0101-81752007000200005.

BUENO, A.A.P., BOND-BUCKUP, G. and FERREIRA, B.D.P., 2003. Estrutura da comunidade de invertebrados bentônicos em dois cursos d'água do Rio Grande do Sul, Brasil. Revista Brasileira de Zoologia, vol. 20, no. 1, pp. 115-125. http://dx.doi. org/10.1590/S0101-81752003000100014.

BUSS, D.F., BAPTISTA, D.F., SILVEIRA, M.P., NESSIMIAN, J.L. and DORVILLÉ, L.F.M., 2002. Influence of water chemistry and environmental degradation on macroinvertebrate assemblage in a river basin in South-Est Brazil. Hydrobiologia, vol. 481, no. 1/3, pp. 125-136. http://dx.doi.org/10.1023/A:1021281508709.

CARTER, J.H.G., CRISTIAN, R.A., LAURIE, C.A., RAFAEL, A., ALEXANDER, S.B., ARTHUR, E.B., DAVID, C.C., MATTHEW, C., CHEN, J., JOHN, C.W.C., GRACIELA, D., HENK, H.D., FANG, Z., RONALD, N.G., VERA, A.G., IRINA, A.G., PETER, J.H., JOSEPH, H., MICHAEL, H., WALTER, R.H., JORGEN, H., JIANG, B., PAUL, J., LISA, K., KARL, K., JENS, K., JIŘÍ, K., DEUSANA, M., NIKOLAUS, M.A.N.A., JEAN-PIERRE, M., CHRISTOPHER, A.M., PETER, U.M., SIMON, M., LIDIYA, N.A., SACIT, Ö., JOHN, P.J.R., INGA, V.P., JOSE, M.P., SERGEY, P., TERESA, S., ANDRÉ, F., ROBERT, W.S., IRINA, I.S., JAVIER, H.S., VLADIMIR, V.S.,
PETER, W.S., THOMAS, S.J.B.W.G.L.W. and THOMAS, Y., 2011. A Synoptical Classification of the Bivalvia (Mollusca). Paleontological Contributions, no. 4, pp. 1-49.

COLWELL, R.K. and CODDINGTON, J.A., 1994. Estimating terrestrial biodiversity through extrapolation. Philosophical Transactions of the Royal Society of London, vol. 345, no. 1311, pp. 101-118. http://dx.doi.org/10.1098/rstb.1994.0091. PMid:7972351.

COSTA, C., IDE, S. and SIMONKA, C.E., 2006. Insetos imaturos: metamorfose e identificação. Ribeirão Preto: Holos Editora. 249 p.

ESTEVES, F.L., 1998. Fundamentos de Limnologia. Rio de Janeiro: Interciência. 602 p.

FRANZ I.; CAPELATTI, L. and BARROS, M.P., 2010. Bird community in a forest patch isolated by the urban matrix at the Sinos River basin, Rio Grande do Sul State, Brazil, with comments on the possible local defaunation. Brazilian Journal of Biology $=$ Revista Brasleira de Biologia, vol. 70, no. 4, suppl., pp. 1137-1148.

FROEHLICH, C.G., org., 2007 [viewed 06 August 2013]. Guia on-line: Identificação de larvas de Insetos Aquáticos do Estado de São Paulo. Ribeirão Preto: FFCLRP. Availale from: http:// sites.ffclrp.usp.br/aguadoce/Guia_online/

FUNDAÇÃO ESTADUAL DE PROTEÇÃO AMBIENTAL HENRIQUE LUIZ ROESSLER - FEPAM, 2014. [viewed 01 September 2014]. Available from: http://www.fepam.rs.gov.br/

FUNDAÇÃO SOS MATA ATLÂNTICA, 2014. Atlas dos remanescentes florestais de mata Atlântica. Periodo 2012-2013. São Paulo: Fundação Fundação S.O.S. Mata Atlântica. 61 p. Relatório Técnico.

GALDEAN, N., CALLISTO, M. and BARBOSA, F.A.R., 2001. Biodiversity assessment of benthic macroinvertebrates in altitudinal lotic ecosystems of Serra do Cipó (MG, Brazil). Brazilian Journal of Biology = Revista Brasleira de Biologia, vol. 61, no. 2, pp. 239-248. http://dx.doi.org/10.1590/S0034-71082001000200006. PMid:11514891.

HAMMER, Ø., HARPER, D.A.T. and RYAN, P.D., 2001 [viewed 14 August 2014]. PAST: paleontological statistics software package for education and data analysis. Palaeontologia Electronica, vol. 4, no. 1, pp. 9 Version 2.16. Available from: http://folk.uio.no/ ohammer/past/

HAWKES, H.A., 1975. River zonation and classification. In: B.A. WHITTON, ed. River Ecology. Oxford: Blackwell Scientific Publications, pp. 312-374

INSTITUTO BRASILEIRO DE GEOGRAFIA E ESTATÍSTICA - IBGE, 2010 [viewed 29 August 2014]. Available from: http:// www.ibge.com.br.

ISMAEL, D., VALENTI, W.C., MATSUMURA-TUNDISI, T. and ROCHA, O., 1999. Síntese. In: D. ISMAEL, W.C. VALENTI, T. MATSUMURA-TUNDISI and O. ROCHA, eds. Biodiversidade do Estado de São Paulo, Brasil: sintese do conhecimento ao final do século XX, 4: Invertebrados de Água Doce. São Paulo: FAPESP, pp. 169-178.

KIKUCHI, R.M. and UIEDA, V.S., 1998. Composição da comunidade de invertebrados aquáticos de um ambiente lótico tropical e sua variação espacial e temporal. In: J.L. NESSIMIAN and A.L. CARVALHO, eds. Ecologia de Insetos Aquáticos. Rio de Janeiro: PPGEUFRJ, pp. 157-172. Oecologia Brasiliensis, vol. 5.

LOPRETTO, E.C. and TELL, G., 1995. Ecossistemas de Aguas Continentales: metodologias para su estudio. La Plata: Ediciones Sur. 325 p. 
MACEDO, J.C., 2010. Monitorameto da qualidade das águas dos Rio dos Sinos. Novo Hamburgo: Centro Universitário Feevale, 184 p. Dissertação de Mestrado em Qualidade Ambiental.

MALTCHIK, L., ROLON, A.S. and STENERT, C., 2010. Aquatic macrophyte and macroinvertebrate diversity and conservation in wetlands of the Sinos River basin. Brazilian Journal of Biology = Revista Brasleira de Biologia, vol. 70, no. 4, suppl., pp. 1179-1184.

MANSUR, M.C.D. and PEREIRA, D., 2006. Bivalves límnicos da bacia do Rio dos Sinos, Rio Grande do Sul, Brasil (Bivalvia, Unionoida, Veneroida e Mytiloidea). Revista Brasileira de Zoologia, vol. 23, no. 4, pp. 1123-1147. http://dx.doi.org/10.1590/ S0101-81752006000400021.

MERRIT, R.W. and CUMMINS, K.W., 1996. An introduction to the aquatic insects of the North America. Iowa: Hunt Publisching Company.

MILESI, S.V., BIASI, C., RESTELLO, R.M. and HEPP, L.U., 2009. Distribution of benthic macroinvertebrates in Subtropical streams (Rio Grande do Sul, Brazil). Acta Limnologica Brasiliensia, vol. 21, no. 4, pp. 419-429.

MORETTI, M.S., 2004. Atlas de identificação rápida dos principais grupos de macroinvertebrados bentônicos. Belo Horizonte: Universidade Federal de Minas Gerais. 6 p.

MUGNAI, R., NESSIMIAN, J.L. and BAPTISTA, D.F., 2010. Manual de identificação de macroinvertebrados aquáticos do Estado do Rio de Janeiro. Rio de Janeiro: Technical Books. 198 p.

PIEDRAS, S.R.N., BAGER, A., MORAES, P.R.R., ISOLDI, L.A., FERREIRA, O.G.L. and HEEMANN, C., 2006. Macroinvertebrados bentônicos como indicadores de qualidade de água na Barragem Santa Bárbara, Pelotas, RS, Brasil. Ciência Rural, vol. 36, no. 2, pp. 494-500. http://dx.doi.org/10.1590/S0103-84782006000200020.

RICE, E.W., BAIRD, R.B., EATON, A.D. and CLESCERI, L.S., eds. 2012. Standard methods for the examination of water and wastewater. 22nd ed. Washington: American Public Health Association. 1496 p.

ROSENBERG, D.M. and RESH, V.H., 1993. Freshwater biomonitoring and benthic macroinvertebrates. New York: Chapman \& Hall. 488 p.
SALLES, F.F., SILVA, E.R., SERRÃO, J.E. and FRANCISCHETTI, C.N., 2004. Baetidae (Ephemeroptera) na região sudeste do Brasil: novos registros e chave para os gêneros no estágio ninfal. Neotropical Entomology, vol. 33, no. 5, pp. 725-735. http://dx.doi. org/10.1590/S1519-566X2004000600010.

SCHÄFER, A., 1985. Fundamentos de Ecologia e Biogeografia das águas continentais. Porto Alegre: Editora da UFRGS. 533 p.

SILVEIRA, M.P. and QUEIROZ, J.F., 2006. Uso de coletores com substrato artificial para monitoramento biológico de qualidade de água. Comunicado Técnico Embrapa, vol. 39, pp. 1516-1638.

SPILKI, F.R., and TUNDISI, J.G., 2010. Priority targets for environmental reserarch in the Sinos River basin. Brazilian Journal of Biology $=$ Revista Brasleira de Biologia, vol. 70, no. 4, suppl., pp. 1245-1247.

STENERT, C., SANTOS, E.M. and MALTCHIK, L., 2004. Levantamento da diversidade de macroinvertebrados em áreas úmidas do Rio Grande do Sul (Brasil). Acta Biologica Leopoldensia, vol. 26 , no. 2 , pp. 225-240.

STRIEDER, M.N., SANTOS, J.E. and VIEIRA, E.M., 2006. Distribuição, abundância e diversidade de Simuliidae (Diptera) em uma bacia hidrográfica impactada no sul do Brasil. Revista Brasileira de Entomologia, vol. 50, no. 1, pp. 119-124. http:// dx.doi.org/10.1590/S0085-56262006000100018.

TUNDISI, J.G. and MATSUMURA-TUNDISI, T., 2003. Integration of Research ans Management in Optimizing uses of Reservoirs: The Experience in South America and Brazilian Case Studies. Hydrobiologia, Baarn. Holand, vol. 500, pp. 231-242.

VOLKMER-RIBEIRO, C., GUADAGNIN, D.L., ROSA-BARBOSA, R., SILVA, M.M., DRÜGG-HAHN, S., LOPES-PITONI, V.L., GASTAL, H.A.O., BARROS, M.P. and DEMAMAN, L.V., 2004. A polyethylenetherephthalate (PET) device for sampling freshwater benthic macroinvertebrates. Brazilian Journal of Biology $=$ Revista Brasileira de Biologia, vol. 64, no. 3a, pp. 531-541. http://dx.doi.org/10.1590/S1519-69842004000300016. PMid: 15622850. 